\section{解説 Explanation}

\section{生物多様性と外来種について}

-外来種問題の議論を深めるために

\section{1. はじめに}

特定外来生物による生態系等に係る被害の防止に関 寸る法律が, 平成 16 年の 6 月に制定されてから 8 年が 過ぎた. 平成 22 年に環境省から公表された「平成 22 年度外来生物法施行状況評価検討報告書」 ${ }^{1)}$ による, 平成 22 年度末までに 102 種の生物が特定外来生物とし て指定され，148種の要注意外来生物が選定されてお り, 普及啓発の効果も上がっているとしている.また, 特定外来生物の飼養などを原則禁止したことにより， 生態系などへの被害の防止に大きな効果を発揮し, 定 着後の特定外来生物への対策についても, 完全排除や 農業被害の緩和など一定の成果が得られた事例も出て きている.

一方で, 要注意外来生物の見直しの必要性や, 定着 前の特定外来種についての種同定やモニタリング調査 の体制の拡充 - 強化, あるいは定着後の特定外来生物 についても, 効果的な防除を推進するための戦略的な 展開の必要性などが指摘されている.

そこで，本報告では外来種が生物多様性に与える影 響について考察しながら, 外来種問題への対策や今後 の課題について述べる.

\section{2. 外来種と移入種について}

外来種に関する用語としては，移入種，外来生物， 帰化動物といった用語があるが，中央環境審議会によ る「移入種対策に関する措置のあり方」 ${ }^{2}$ では，生物 学用語との整合性の観点から外来種という用語が適切 であるとの強い指摘があったことから，移入種ではな く外来種という用語を用いている. 一方で, 野生生物 保護対策検討会移入種問題分科会が報告した, 「移入種

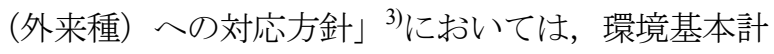
画や生物多様性国家戦略では移入種という用語が用い られているが，外来種という用語も同様の意味で使用 されているとの理由から, 移入種 (外来種) と記載し ている. なお， 2002 年に公表された新・生物多様性国 家戦略においても移入種という用語が使用されている が, 2007 年に公表された第三次生物多様性国家戦略で
は外来種という用語が用いられている.

一方，外来生物という用語についてであるが，上述 した特定外来生物による生態系等に係る被害の防止に 関する法律は外来生物法と略されており，さらに，飼 育, 栽培, 保管, 運搬, 輸入等が原則禁止となる生物 に対しては，特定外来生物との用語を用いて対応して いる. ただし，法律の第二条に記載されている特定外 来生物の定義を読むと，外来種や移入種という用語の 意味する内容と同じであると思われる。 したがって, 外来種，移入種，外来生物という用語は基本的には同 じ内容を意味しており，特段の区別をする必要は無い と思われるが，外来生物に関する問題を一般的に”外 来種問題” と呼ぶことが多いことなどから，本稿では 外来種という用語を用いる。 また，特に植物を扱う場 合には史前帰化植物という用語を用いる場合もあるが, 生物全般を対象とした場合には外来種という用語の方 が多く使われている.

なお，帰化動物という用語については，外国から輸 入された外国産動物が動物園などの施設で飼育管理さ れた状態（introduced state）を外来生物, 飼育管理され ていた動物が逸出したり，あるいは野外に放たれて自 然繁殖し定着した状態 (naturalized state) を帰化生物と して大別している事例も見られる ${ }^{4)}$. 外来種問題につ いて検討寸る際に対象生物が人間の管理下にあるのか, そうではない状態にあるのかの差は大きいと考えられ るが，用語の扱いが煩雑になるため，本稿では管理下 にない場合全般を外来種問題として取扱う.

\section{3. 外来種問題とは}

「移入種（外来種）への対応方針」3)では，2002 年 の生物多様性条約第 6 回締約国会議で採択された，生 物多様性条約における外来種の指針原則にしたがい, 外来種（Alien species）を「過去あるいは現在の自然分 布域外に導入された生物で, 生存し増殖することが出 来る器官，配偶子，種子，卵，無性的繁殖子を含む」 とし，外来種のうち導入又は拡散した場合に在来の生 物多様性を脅か寸種を，特に侵略的外来種（Invasive 
alien species）としている. この定義では，自然分布域 外に導入された方法についての記載はないが，導入

(Introduction) について「外来種を直接・間接を問わ ず人為的に，過去あるいは現在の自然分布域外へ移動 させること」と定義しており, 導入が人為的な原因に よることを明確に示している.さらに，同定義の記述 には，「この移動には，国内移動，国家間または国家の 管轄範囲外の区域との間の移動があり得る」としてい ることから，同一国内において人為的に移動した生物 も外来種に含まれると解釈される。 また, 定着

（Establishment）とは，外来種が新しい生息地で，継 続的に生存可能な子孫を作る状態であるとしている.

ところで，いつの時代に導入された生物から外来種 とするかについては，分類に関する科学的情報が明治 時代以降に整理されたことや，海外との貿易や物流は 鎖国が終った明治時代以降に飛躍的に増大することか ら，明治維新以降に導入された生物を外来種とする考 え方がある ${ }^{2)}$ ，この説明は受入れやすいが，日本の歴 史だけを考慮しているため, 海外においては別の基準 を採用する必要があると思われる，ちなみに，米国や 欧州の生物多様性保全に関する事例が多く引用されて いる Conservation Biology（日本語訳 : 保全生物学）を 読むと，ヒトは地球上全体に分散するのに伴い他の生 物種を移動させたことも多く，こうした外来種の侵入 が在来種の生物多様性に重大な影響を与える場合があ ったと記載されており，時代や国境の制限を明確にし ていないように思える5).

外来種が問題となる原因は，他地域から導入された 生物が導入先の生態系や生物多様性に対して悪影響を 与えることである. 外来種が在来種に対して与える悪 影響としては，捕食者あるいは病原菌の保有者として の影響, 競争者としての影響, 環境改変者としての影 響及び在来の近縁種と交雑することによる影響などが 考えられる. ただし, 導入された全ての外来種が定着 するわけではない. 新たな地域に導入された外来種は, 人為的に持込まれた個体群からスタートし，導入先の 土地で維持されている生態系の中で環境確率性, 人口 学的確率性, 遺伝的確率性といった絶滅要因を乗り越 えた上で，安定した増殖システムを確立して個体数を 増やし新たな地域に定着する. Williamson (1993)は様々 な事例を取り纏め, 海外から持ち込まれた外来種が野 外に逸出して繁殖に成功する確率, 繁殖した外来種が 自然下で個体群を維持する確率，野生下で個体群を維 持している外来種が在来の生態系などに悪影響を与え る確率が, 各々 5\%〜20\%の範囲であり平均すると $10 \%$ であることを示した ${ }^{6}$. 必ずしも全ての事例が，この 範囲であるとは言えないと思うが，凡その数字として 参考になると思われる. また, 導入地域に定着した外
来種は，個体群を維持出来るだけの個体数まで増加し た後，次第に近隣の地域に分布域を広げていく．その パターンとしては，分布域が一定の速度で拡大してい く場合 (創始個体群の周縁から拡大), 初期の拡大速度 は遅いが次第に速度を上げていく場合（創始個体群が 周縁に分散した個体群と融合しながら拡大), そして拡 大速度が時間とともに増加する場合（創始個体群から 離れた場所に分散した個体群が次々に増殖拡大）とい ったパターンが認められ，これらのパターンは生物の 分散特性によって説明できる ${ }^{5)}$.

\section{4. 生物多様性と外来種問題}

外来種問題は，在来生物に様々な悪影響を与えるこ とから，生物多様性を減少させる大きな要因になると 思われる．生物多様性の保全に大きく関与する国際的 な条約としては，(1)生物の多様性の保全，(2)その構成 要素の持続可能な利用，(3遺伝資源の利用から生ずる 利益の公正かつ衡平な配分，を目的として掲げている 生物多様性条約がある. 本条約は, 1992 年 6 月に地球 サミットにおいて採択され，1993 年 12 月に発効し， 2012 年 2 月現在，EC を含む 192 か国及び欧州連合が 締結している (米国は未締結)。本条約の第 10 回締約 国会議(COP10)は, 2010 年 10 月に名古屋において開催 されたが，その際に採択された生物多様性を保全する ための目標（愛知目標）では，5つの戦略目標と 20 の 個別目標が示されている（生物多様性条約ホームペー ジ(http://www.cbd.int/)を参照)．5つの戦略目標の内の 戦略目標 $\mathrm{B}$ 「生物多様性への直接的な圧力を減少させ, 持続可能な利用を促進する」に関連する個別目標 9 に は，「2020 年までに，侵略的外来種とその定着経路が 特定され，優先順位付けられ，優先度の高い種が制御 され又は根絶される．また，侵略的外来種の導入又は 定着を防止するために定着経路を管理するための対策 が講じられる」と記載されており，生物多様性の保全 のためには外来種問題の解決が重要であることが認識 されている.

また，国内において生物多様性を保全するための取 組みの基本となる生物多様性国家戦略は，1995 年に第 一次戦略が策定された後，2002 年に第二次 2007 年に 第三次の国家戦略として改訂され，さらに 2010 年 3 月に「生物多様性国家戦略 2010」が閣議決定された。 生物多様性国家戦略 2010 では生物多様性の危機の構 造として，地球温暖化による危機の他に 3 つの危機を 課題として取り上げている.この 3 つの危機は，第 1 の危機 : 人間活動や開発による危機, 第 2 の危機 : 里 地里山など人間活動の縮小による危機，第 3 の危機 : 
人間により持ち込まれたものによる危機，と説明され ているが，この内の第 3 の危機では人為によって導入 された外来種が，地域固有の生物相や生態系にとって 大きな劦威となっているとして外来種問題を取り上げ ている.このように，外来種問題は生物多樣性を保全 するという大きな目標と関連付けて考えることが重要 である

ところで，外来種の定着は当該地域に分布する生物 が 1 種増えるため, 生物多様性は増加するのではない かとの意見がある．しかしながら，外来種は既に原産 地において分布しており, 新たな地域に定着しても地 球全体としての生物種数は変化しない. むしろ, 外来 種の定着によって，もともと当該地域に分布していた 在来種が悪影響を受け, 最悪の場合には当該地域にし か分布していないような固有種が絶滅し, 当該地域だ けでなく地球全体の生物種数が減少することになる. ある自然環境が収容できる生物種の数は，空間的にも 物質的にも限られており, 外来種の侵入は在来種にと っては負の影響が及ぶ可能性の方が高い 7). さらに, 後述するように当該地域に維持されている遺伝的諸特 徵は, 独自の歴史を反映しているため, 遺伝的多様性 という観点から見ると, 外来種の定着は在来生物種に 対して悪影響しかもたらさない ${ }^{8)}$.

\section{5. 具体的な事例}

海洋における外来種の事例として, 最も良く知られ ている生物としてはムラサキイガイがある.ムラサキ イガイが日本国内において初めて発見された時期につ いては, 1920 年代から 1930 年代まで複数の説が存在 するが，これらの資料から推定すると 1920 年直前か, それ以前に日本に移入したと考えられ，移入手段とし ては主に外国航路の船舶に付着して導入されたと推定 されている 9).ムラサキイガイの導入経路としては, 北米西岸やヨーロッパなどが考えられるが，ヨーロッ パからの場合には船舶がインド洋やマラッカ海峡とい った高水温域を通過すると思われる. ムラサキイガイ の成貝は, $20^{\circ} \mathrm{C} \sim 30^{\circ} \mathrm{C}$ 水温が続くと死滅すると考え られているが，温帯種が赤道海域の高水温域を超えて 分散した事例があることや，ムラサキイガイが北半球 から南半球へ移入したことを示唆する結果が遺伝学的 な研究から得られていることから, 本種がヨーロッパ から赤道付近を経由して日本に導入されても不自然で はない，したがって，ムラサキイガイは様々な外交航 路を使って世界中に分散する能力を持つと思われるが, 現在では日本国内に定着したムラサキイガイが，北米 やオーストラリアなどへ再導入されている可能性が示
唆されている ${ }^{9}$.

既に定着した外来種が在来種に与える様々な悪影響 を解決するためには外来種を根絶する必要があるが， 駆逐するのが難しい事例として種間交雑による遺伝学 的な影響がある．種間交雑の影響は様々であるが，外 見だけでは交雑個体を判別しにくいことや，遺伝子レ ベルでの影響は問題が表面化し難いことなどから，雑 種個体を識別して駆除することは非常に困難である. さらに, 雑種個体が在来種と戻し交配するような場合 には，外部形態が在来種に類似してくると予想される が，外来種の遺伝子は残っているため，一度雑種個体 が入り込んだ集団では, 純粋な在来種の遺伝子系統を 維持することは現実的には不可能に近い.

このような事例としては, ペットとして販売されて いるスマトラオオヒラタクワガタがある. 本種は, 日 本産のオオヒラタクワガタとの間で交雑し, 両種の間 で得られた雑種卵全てが捊化した後, 約 7 割が成長し たとの実駼結果が報告されている ${ }^{10)}$. 一般的に種が異 なる生物同士が交配しても，受精卵が正常に発生しな かったり，雑種個体が繁殖力を持たないなど，一過性 で終る場合が多い，しかしながら，オオヒラタクワガ 夕の場合には, F1 雑種同士を交配させた 4 組のペアか ら F2 が得られたことが報告されており, 雑種個体の 系統が広がっていく可能性が危惧される. スマトラオ オヒラタクワガタと日本産ヒラタクワガタは遺伝的に 離れていることが示されているが，本事例の場合には 両種の間で生殖的な隔離機構が発達しないまま, 地理 的隔離によって異所的に種（系統）が分化したと推察 されている. このように，両種の間に遺伝子交流が成 立しうるという結果から，スマトラオオヒラタクワガ タが日本国内で野生化した場合, 遺伝的攪乱のリスク は低くないと結論付けられている ${ }^{10)}$.

外来種が近縁の在来種と交雑することによる問題に は様々なタイプがあるが，人為的な外来種導入に伴う 影響としては，遺伝子浸透を伴わない場合

(nonintrogressive hybridization) と，ヒラタクワガタの 事例のように遺伝子浸透を伴う場合（introgressive hybridization）とに大別できる. 遺伝子浸透を伴わない 場合としては，コイ科の小型淡水魚であるモツゴ（図 1）とシナイモツゴの例がある. 両種はフォッサマグナ を境として，西日本 (モツゴ) と東日本（シナイモツ ゴ）とに分布域を分けているが, 20 世紀後半には人為 的な導入によりモツゴが全国的に分布域を拡大したの に対して，シナイモツゴの分布域は著しく減少してい る. 両種の場合には, 遺伝子浸透を伴わないため F1 雑種は妊性を持たないが，実際に自然界において交雑 が行われているため，両種にとって繁殖資源の浪費と いう問題が生じる，なお，両種は飼育下においては正 
逆交雑が可能であるが，野生下においてはシナイモツ ゴの雌とモツゴの雄の交雑により生じた F1 雑種が優 先的に見られる。一般的に，配偶子の生産において卵 は精子よりも多くのエネルギーを要するため, 雌種の 方が雄種よりも個体群動態学的影響を受けやすいとい う特徴がある。ささらに，モツゴの方が成長や繁殖率に おいてシナイモツゴよりも優位であることなども影響 して, シナイモツゴの分布域減少という結果に繋がっ ていると思われる ${ }^{11}$.

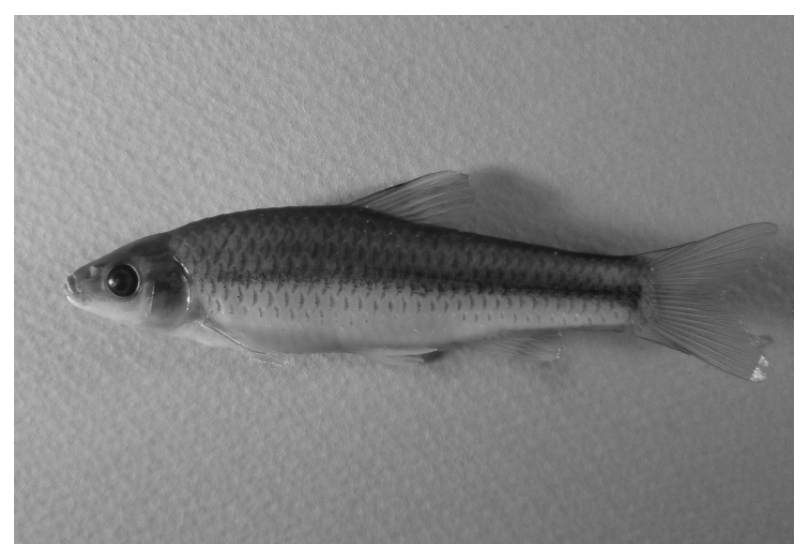

図 1 シナイモツゴへの影響が問題になっているモツゴ

一方，遺伝子浸透を伴う場合としては，ニッポンバ ラタナゴとタイリクバラタナゴ (図 2) の事例が有名 である.タイリクバラタナゴは 1940 年代に中国から輸 入されたソウギョなどの淡水魚に混じって国内に導入 されたと考えられており, 外来生物法において要注意 外来生物リストに記載されている。 この事例において は,タイリクバラタナゴの分布域が拡大寸るとともに, 日本在来のニッポンバラタナゴの分布域は減少し，本 州と四国では一部の溜池を除いて絶滅したとされてい る. ニッポンバラタナゴ激减の最大の理由はタイリク バラタナゴとの交雑であり，実際にニッポンバラタナ ت゙が絶滅した水域の多くでは交雑個体が優先した状態 となっている ${ }^{11)}$.さらに深刻なのは, タイリクバラタ ナゴ，ニッポンバラタナゴ，両種の雑種個体を外見か ら区別することが難しいため, タイリクバラタナゴ及 び雑種個体の駆除が非常に難しいことである。このま まの状態では，気が付かない内にニッポンバラタナゴ が地球上から絶滅してしまうといった最悪のケースも 考えられる.

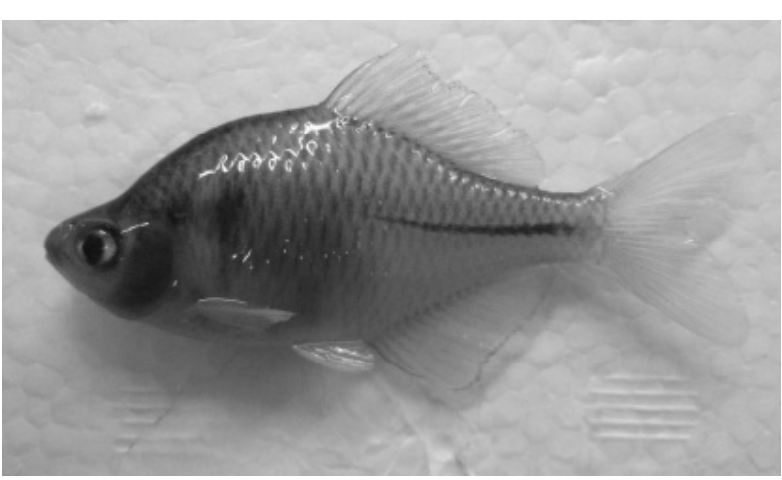

図 2 ニッポンバラタナゴへの影響が問題となっているタイ リクバラタナゴ

\section{6. 外来種問題への対策}

外来種問題への対策は，導入及び定着の防止と定着 後の駆除とに大きく分かれるが，定着した外来種を根 絶するためには非常に大きな労力を要することから, 導入及び定着の段階において対応することが重要であ る. しかしながら，導入の段階では個体数が少ないた めに発見するのが遅れ，外来種の存在が確認された時 点においては，既に導入の段階ではなく定着して個体 数が増加した段階に達している場合も多い. したがっ て，実際に導入された事実が確認されなくても，外来 種が導入される可能性が認められた時点で，導入の防 止対策をとり，導入によるリスクをゼロにすることが 重要である．また，導入後においても外来種の繁殖を 防ぐことにより，定着してしまう前に対処する必要が ある. 外来種が定着して個体数が増加してしまった後 で駆除対策をとった場合には，最初のうちは捕獲努力 量の増加とともに捕獲効率も増加するが，根絶の状況 に近づくと捕獲効率が下がる可能性が高く, 残り 1 割 を捕獲して根絶寸るためには非常に大きなコストと労 力が必要になる ${ }^{12}$.

外来種が侵入する最初の段階である導入は，人為に よって意図的に行われる意図的導入 (Intentional introduction）と，人為であっても意図的ではない非意 図的導入 (Unintentional introduction) とに分類される 3)．意図的導入を防ぐためには，外来種の逸出を確実 に防止できる管理体制が取れない限り，導入を原則禁 止にするべきである．したがって，導入を禁止するリ スト（ネガティブリスト）で規制するのではなく，例 外的に導入を許可するリスト（ポジティブリスト）で 規制した方が効果的であると思われるが，外来種の導 入を禁止することにより経済活動が制限されるなどの 影響が考えられることから，外来生物法ではネガティ ブリストという考え方を採用している．もちろん，ネ 
ガティブリストを用いても一定の効果が期待されるが, リストの更新や再検討を随時行う必要があると思われ る.

上述したように，全ての外来種が定着するわけでは なく, ある一定の条件が必要だと思われる。一般的に 定着しや寸い外来種には, ある条件下において個体数 を短時間のうちに増加できるような繁殖力の高い種, 生息地や食性などについて適応力が高く幅広い資源を 利用出来る種，短期間のうちに生息適地を探し出せる 分散能力の高い種，などの条件を揃えている場合が多 く認められる. また，船舶のバラスト水によって導入 される可能性の高いカイアシ類については, 北米太平 洋沿岸で確認された, 東アジア原産のカイアシ類につ いての報告がある．本報告によると，これらのカイア シ類に共通している特徴として, (1)東アジアの熱帯〜 温帯の, 汽水域〜強内湾域に生息している, (2)カラヌ ス目の場合, 全種がディアプトムス上科 Diaptomoidea に属する，(3)貧酸素に強い場合が多い，(4)休眠期がな く年中出現する種が多い，といった項目があげられて いる ${ }^{13)}$. 一方, 外来種が定着しや寸い場所としては, 空いたニッチが存在する攪乱された地域，生物多様性 が低く生物群集や食物網が単純である地域, 外来種を 捕食する天敵が少ない地域，あるいは外来種により捕 食される生物種が多い地域（特に被捕食者が捕食に対 する適応能力が不十分な場合）などがある ${ }^{5)}$. したが つて, 社会生活の広がりにつれて, 工業化や都市化が 進み, これまでとは異なる環境の生息場所が新たに出 現した場合には，その地域は空いたニッチが存在する だけでなく，生物相が貧弱なために天敵や競合種が少 ない地域に該当し, 外来種が侵入しやすい場所である と考えられる. また, 海洋環境においてはマリーナ建 設や護岸整備などにより新たに出現した生息域や，富 栄養化したことにより生息環境の質が変化したような 海域が，外来種の侵入しや寸い場所として考えられる 9). この様な生物学的特徵や環境条件などにも配慮し ながら，外来種問題への対策を検討寸る必要があると 思われる。

\section{7. 外来種問題の課題}

以上，外来種は在来の生物や生態系に大きなインパ クトを与えるため, 生物多様性を保全するためには外 来種の導入経路を絶ち, 繁殖機会を防ぎ, 定着個体を 駆除する必要があることを述べてきた，とくに，定着 する前の段階であるほど外来種対策に関するコストや 労力は低く効果も高いと思われる. そのため, 外来種 の導入を早期に発見する必要があるが，全国規模で外
来種の導入状況をモニタリングするのは現実的に考え ると非常に困難である. 特に海洋生物の場合には, 多 量の卵やプランクトン幼生が海洋環境の変化により大 発生する場合も多く, 被害発生の予測は困難であるこ とから，やはり予防原則に基づいて導入の機会を極力 削減することが課題になると思われる ${ }^{14)}$. さらに, 分 類学的研究の不足も大きな課題である. 例えば, 外来 種のモニタリングを実施する際には, 学術標本やサン プルを正しく同定し管理する能力を持った，パラタク ソノミストが必要となる，とくに，同定が難しいこと や分布域を含めた生物学的知見が少ないなどの理由に より，移入種かどうかを判断することが難しい多毛類 などについては，パラタクソノミストの養成は急務で ある ${ }^{15)}$.

ところで，冒頭で述べたように外来生物法が制定さ れて数年が経過し, 国や研究機関などによる様々な外 来種問題への取組みが行われ，その成果も少しずつ得 られてきている ${ }^{1)}$. しかしながら, 既に定着して問題 が表面化している場合も多く, 駆除活動から始めざる をえないケースも多く見られる. 駆除には毒殺や銃殺 といった手法が用いられるが，故意かどうかは別とし て人間が持込んだ生物を，外来種だからという理由で 駆除することを素直に正当化することは，感情的には 難しいと思われる. 生物多様性の保全という目標を掲 げてはいるが, 野生生物に対しては個々の命ではなく, 種という単位が保全の対象であるという考え方は理屈 では理解出来るが，実行するのに躊躇してしまう場合 も考えられる.

確かに全ての野生生物個体を保全することは現実的 に不可能であり, 外来種が原因で多くの種が絶滅の危 機に瀕している状況においては, 地球上の生物多様性 を維持するために，種を単位として保全するという考 え方は重要である.もちろん, 外来種も原産地におい ては生物多様性を支える貴重な生物の一種である。し たがって, 逆に原産地において他地域から導入された 外来種により悪影響を受けているようであれば，その 外来種を駆除することによって種を保全するのであり, 外来種だからといって, その生物種を地球上から絶滅 させようという意図はない，それでも，単純に外来種 =悪い生物という図式で外来種を駆除していくことで, 本当に生物多様性を守れるのかについての議論が必要 である，上述したように，外来種対策には非常に大き なコストが必要となるが, 外来種の導入あるいは定着 に関して，どのようにして誰が責任を負うのかを明確 にすることは難しい，したがって，必要となる経費は 国や地方自治体で賄う必要が出てくるが，そのような 場合においても関係者の間で外来種問題が十分に理解 されているかが重要になってくる. 
外来種問題は, 在来生態系への影響が表面化するま で，外来種の発見が遅れることが解決を難しくしてい るが，上述したように発見すること自体が難しい問題 として遺伝的攪乱がある. 生物は構成する集団内にお いて, 各個体に生じた突然変異の割合を, 自然選択や 遺伝的浮動などにより拡大したり，あるいは集団から 消滅させたりしている，この過程において，より分布 域の環境条件に適した遺伝子を持つ個体は子孫を増や していくため, 野生生物集団では生息環境に適した遺 伝子組成を持つ個体が優先していると思われる. した がって, 遺伝的交流の無い集団同士は, 各々の生息海 域に適した遺伝子組成を維持しており，異なる集団間 で個体を移動させると, 最適な遺伝子組成が崩れる可 能性が生じる. さらに, 各集団が維持している遺伝的 な多様性は, 集団が成立してから現在に至るまでに集 団が経験した生息環境や集団構造の変化などを反映し ている. 例えば, 複数の集団について遺伝学的な特徴 を調べることにより，過去にどのような分散をしてき たのか，あるいは集団間での交流があったかについて 検討することが可能である ${ }^{8}$. ᄂ しかしながら，異なる 歴史的背景を持つ別の集団からの個体が導入されると， 集団が維持していた固有の遺伝的特徵が攪乱され，反 映されていた歴史的背景が見えなくなってしまう。

遺伝的攪乱が生じているかを確認寸るためには，遺 伝学的な分析が必要であるため, 問題が生じているこ とを発見するのは非常に難しい，さらに，遺伝的なレ ベルでの外来種問題で重要なことは, 生息環境に適し た遺伝的特徵や歴史的背景への影響を考えると，同一 種の導入でも問題が生じるということである. したが って，遺伝的攪乱に関する問題を解決するためには， 全ての生物の導入を防止する以外に解決手段は無い. 遺伝的攪乱が予想される全ての導入経路を遮断するこ とは現実的に不可能であるが，遺伝的攪乱が野生生物 集団に与える悪影響に関する認識を幅広く伝え，各人 が遺伝的攪乱を防止する必要性を認識することが問題 解決への第一歩だと思われる.

\section{8. まとめ}

生物多様性を保全するためには，外来種の導入や定 着あるいは繁殖を防ぎ, 増加した個体を駆除寸る必要 がある，その対応自体は間違っていないが，それだけ では生物多様性を保全することは困難である. 外来種 問題だけに焦点をあてて, 生物多様性の保全を議論し ていては，既に生活環境に馴染んでいるアメリカザリ ガニを駆逐すべきだと即答することは難しい. 外来種 自体は悪者ではなく, 外来種駆除は青少年の健全な発
達に良い影響を与えないといった考え方は行き過ぎで あるが，生物多様性とは何か，我々は何を保全しよう としているのかについて真剣に検討し，外来種問題に 関して正しい知識を多くの人に広め，理解を深めてい く必要がある ${ }^{16}$.

様々な化石記録から，人類が地球上に出現する以前 は 1 年あたり $1 \sim 10$ 種の割合で, 野生生物が絶滅して いたと言われているが，次々に新しい生物種が出現し てきたことにより, 地球上の生物種の数は一定のレベ ルに維持されてきた．しかしながら，現代における鳥 類と哺乳類の絶滅率は 100 年当たり約 $1 \%$ と推定され ており，上述した人類出現前の時点に比較すると 100 ～1,000 倍もの勢いで絶滅が進んでいるとの計算にな る. また, 地球上の森林面積から生物の絶滅率を推定 すると，さらに值は大きくなるとされ，現在では地球 上の生物種数は非常な速度で減少している傾向にある と考えられる ${ }^{17}$. 現在, 我々が目にすることの出来る 生物は, 我々の祖先が絶滅させないで受け渡してくれ た生物である。もちろん，既に絶滅して受け渡されな かった生物も存在するが，35 億年以上と言われる長い 年月をかけて，漸く地球上に姿を現した生物種を次の 世代に引き継ぐことは我々の責務である，その責務を 果たすために, 我々が解決すべき問題は山積している が，諦めずに努力していくことが重要である.

\section{参考文献}

1）環境省，平成 22 年度外来生物法施行状況評価検討 報告書,

http://www. env. go. jp/nature/intro/6document/file s/h22_IAS_Act_report.pdf

2）中央環境審議会，移入種対策に関する措置の在り 方について,

http://www. env. go. jp/council/toshin/t13-h1505. ht ml.

3）野生生物保護対策検討会移入種問題分科会，移入 種 (外来種) への対応方針について, http://www. env. go. jp/nature/report/h14-01/honpen . pdf

4）中村，帰化動物のはなし，（1994）, 技報堂出版. 5) Andrew S. Pullin, Conservation Biology, 井田, 大久保，倉本，夏原共訳，保全生物学，（2004）, 丸善 株式会社.

6)Williamson, M. , Experientia, 49, (1993), 219-224.

7) 北村，水産界，10，(2010），17-22.

8)北村, 泳ぐ DNA, 猿渡編 (2007), 227-251, 東海大学 出版会.

9)大谷, Sessile organisms, 19-2, (2002), 69-92.

10）五箇, 関西自然保護機構会誌，28-1，（2006）, 
37-47.

11）河村ほか 6 名, 日本生態学会誌 59, (2009), 131-143.

12)松田, 生態リスク学入門, (2008)，65-94，共立出 版.

13）大塚，日本プランクトン学会報，55-2，(2008）, 115-126.

14) 岩崎, 日本水産学会誌，73-6, (2007)， 1121-1124.

15) 西, 加藤, 日本ベントス学会誌，59, (2004), 83-95.

16)佐藤, 環境情報科学，33-1，(2004）, 26-30.

17) 井上, 和田編, 岩波講座地球環境学 5 , 生物多様 性とその保全，（1998），197-229，岩波書店.

\section{著者紹介}

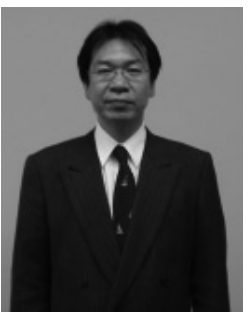

北村 徹

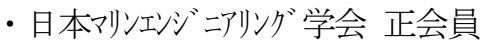

・1967 年生.

・日本エヌ・ユー・エス株式会社.

·長崎大学大学院海洋生産科学研

究科.

·分子生物学. 